\title{
Tinjauan Sistem Proporsional Terbuka Dalam Pemilu Legislatif 2019 Terhadap Dinamika Demokrasi Di Indonesia (Studi Kasus Di Kota Pekan Baru)
}

\author{
M. Rizqi Azmi ${ }^{1}$, Riko Riyanda ${ }^{2}$ \\ Faculty of Law, Universitas Islam Riau.E-mail: mrizqiazmi@law.uir.ac.id
}

\begin{abstract}
In the 2019 DPR RI and Provincial, Regency and City (DPRD) DPRD elections, elections were conducted through an open proportional system. In Pekanbaru City, they also feel the same enthusiasm, proportional euphoria is open to election participants. However, this system also contains weaknesses according to the theory, including: Voters' political participation is damaged by political pragmatism in competing for votes so that on the one hand money politics or vote buying and selling are more prevalent, on the other hand political costs are getting more expensive, which encourages the people to corruption. Second, political parties are still dominated by a handful of people who created Politic Oligarch. From the results of the study, it shows that party elites and the voting community in Pekanbaru prefer an open proportional system in the 2019 legislative elections compared to closed proportional ones, there are several considerations such as: (1) An open proportional system is fair enough for legislative competition and can increase transparency in Elections. (2) With an open proportion, it can educate voters through campaign programs. (3) By using any system, the space for political money will always be open. (4) Lower serial numbers still have the opportunity to gain votes. (5) The open proportional system further legitimizes the people's sovereignty in the closed proportional area. (6) The open proportional system further increases voter participation.
\end{abstract}

Keywords: Open Proportional System, Legislative Election, Democracy

\section{Pendahuluan}

Praktek Demokrasi Selama ini berada dalam kungkungan hegemoni teori tertentu, dan keinginan untuk mengaitkan teori demokrasi dengan konteks yang melingkupi stigma tertentu. Keinginan untuik melakukan demokratisasi secara kontekstual diejek sebagai keenggenan atau exuse untuk membayar biaya berdemokrasi. Penyimpangan yang untuk sementara diterima tidak perlu diratapi atau dikutuk, namun tetap saja bisa disiasati penuntasannya dari waktu ke waktu. ${ }^{1}$

Pengalaman banyak negara menunjukkan, praktik demokrasi tidak selalu berjalan linier sesuai kualitasnya.Demokrasi prosedural tetap menjadi dasar bagi berlangsungnya demokrasi dan mengalahkan Demokrasi Substansial. Itulahsebabnya, Pemilu menjadi pangkal bagi perkembangan demokrasi. Artinya, jika Pemilu tidak terlaksana, maka tidak ada harapan bagi bertumbuhnya demokrasi.

1 https://www.republika.co.id/berita/nasional/politik/14/03/19/n2o11c-hasil-riset-ini- jumlah- diakses tanggal 17 agustus 2019. 
Salah satu bentuk demokrasi prosedural dari Pemilu Legislatif dari hasil Pemilu serentak 2019 adalah kegagalan status quo dari sistem proporsional terbuka yang masih dipertahankan dari Pemilu DPR dan DPRD pada tahun 2014. Banyak harapan Rakyat akan keadilan dan kejujuran yang pupus dengan sistem proporsiona terbuka. Apalagi dengan pemilu serentak presiden dan wakil presiden beserta DPR dan DPRD fokus terhadap pemilihan legislatif menjadi kabur dan menjadi pekerjaan bagi makelar untuk menebar virus pragmatis dan kesenangan sesaat kepada pemilih yang notabene adalah rakyat yang nanti akan merasakan dampaknya.

Harapan sebenarnya Dengan sistem proporsional terbuka maka diharapkan rakyat lebih mengetahui lebih dalam tentang calon wakil rakyatnya. Dengan begitu dengan sistem ini akan tercipta suatu demokrasi yang lebih kuat karena rakyat lebih bebas memilih wakil rakyatnya yang akan menyuarakan berbagai aspirasinya di parlemen atau pemerintahan.

Dalam implementasinya sistem ini akan menghambat penguatan demokrasi Indonesia yang mengakibatkan menguatnya ideologi pasar disertai dengan melemahnya ideologi partai politik. Melemahnya ideologi partai ini akan memunculkan suatu perjuangan individualisme partai. Hal ini terlihat dari penelitian Lembaga Penyelidikan Ekonomi dan masyarakat Universitas Indonesia (LPEM UI) dengan semakin membesarnya dana kampanye dari setiap calon legislatif. Sejak diberlakukannya sistem ini biaya kampanye caleg DPR RI meningkat hingga empat kali lipat, yaitu 1,18 Miliar yang sebelumnya berada di angka 250 juta per caleg di tahun 2009. ${ }^{2}$ Dana kampanye ini akan terus meningkat jika sistem ini tetap dipertahankan. Hal ini juga mengakibatkan tergesernya para aktivis partai oleh pengusaha-pengusaha yang memiliki dana yang lebih besar.

Selanjutnya penting untuk disoroti dari sistem pemilu ini adalah proses rekrutmen partai politik yang cenderung mencari kandidat yang populer sehingga punya elektabilitas yang tinggi di mata para pemilih. Hal ini pula yang mendorong banyak artis (sinetron, lawak, penyanyi) yang tergiur untuk bergabung ke dalam sebuah partai politik.

Dari uraian latar belakang masalah di atas, maka penulis merumuskan kajian masalah yaitu terkait praktek status quo Sistem Proporsional Terbuka dalam pemilu legislatif tahun 2019 di Indonesia dengan studi kasus di kota pekanbaru serta bagaimana peran partai politik dalam menyikapi persoalan pemelemahan demokrasi dari Sistem Proporsional Terbuka. Kemudian mencari solusi terhadap pelemahan tersebut untuk mengukur kemajuan demokrasi.

\section{Tujuan Penelitian}

Untuk menganalisa bentuk implementasi dan implikasi dari diberlakukannya status quo Sistem Proporsional terbuka.

Untuk mengetahui mencari solusi terbaik mencari system yang akan digunakan dalam kebijakan pemilu di masa yang akan datang.

\footnotetext{
2 Purwo, Santoyo. 2014“Merancang Arah Baru Demokrasi Indonesia Pasca Reformasi”, Penerbit KPG (Kepustakaan Populer Gramedia), Jakarta.
} 


\section{Metode Penelitian}

Jenis Penelitian ini adalah penelitian deskriptif kualitatif. Penelitian deskriptif kualitatif adalah salah satu metode untuk mendapatkan kebenaran dan tergolong sebagai penelitian ilmiah yang dibangun atas dasar teori-teori yang berkembang dari penelitian dan terkontrol atas dasar empirik. Data dalam masalah penelitian ini bisa berasal dari dokumentasi hasil penelitian, pengawasan, evaluasi, pengamatan pendahuluan dan pernyataan orang-orang yang patut dipercaya. ${ }^{3}$

Data dan Sumber Data. Data Primer yang bersumber dari wawancara langsung dengan Informan. Data Sekunder yang besumber dari bahan-bahan buku, artikel, jurnal serta pendapat para ahli dalam berbagai literatur.

Analisis data dalam penelitian ini dilakukan dengan cara mengkompilasi data, memilih data, dan memilah data, menyusun dan menggabungkan kembali data yang sudah dipilih, menginterpretasikan data, dan menyimpulkan data. ${ }^{4}$

\section{Pembahasan}

\section{A. Penilaian Kelompok Elit Partai Dan Masyarakat Pemilih Kota Pekanbaru Terhadap Kedua Sistem Pemilu.}

1) Sistem Proporsional Terbuka Cukup Adil Bagi Kompetesi Caleg Dan Dapat Mengkatkan Transparansi Dalam Pemilu. Sistem ini memberikan harapan bagi caleg ini berkompetesi secara adil, terbuka dan bisa lebih bersemangat untuk mendapatkan suara. Hubungan dengan konstituen juga lebih dekat secara emosional karena bersentuhan langsung dengan warga dan mengajak warga untuk memillihnya pada saat pemilu. Dengan demikian, sistem proporsional terbuka yang sudah diterapkan bagi informan menguat demokrasi dan demokratisasi di Indonesia, khususnya di partai politik. Sistem proporsional terbuka membuka jalan untuk meningkatkan partisipasi calon lebih meningkat. Kalau calonnya semangat, tentu berimplikasi kepada jumlah pemilih, makanya demokratisasi kita itu semakin menguat ketika jumlah pemilih semakin banyak. Dengan sistem proporsional terbuka ini ingin menghindari tumbuhnya kembali elit partai di dalam menentukan calon-calon terpilihnya.

\section{Dengan Proporsional Terbuka Dapat Mengedukasi Pemilih Lewat Program Kampanye.}

Dengan Proporsional terbuka edukasi kepada masyarakat yang lebih cerdas dalam menyampaikan program mereka, berdialog dengan masyarakat sebaik mungkin, sering terjun ke daerah pemilihannya secara berkala, membuka ruang kepada publik untuk menyampaikan kritik dan sarannya secara langsung terhadap apa yang sesuai dengan kebutuhan mereka.

\footnotetext{
${ }^{3}$ Sugiono. 2012. Metode Penelitian Kuantitatif Kualititatif Dan R \& D. Alfabeta, Bandung, hal. 206

${ }^{4}$ Robert K.Yin. 2011. Qualitiative Research : From Star to Finish, The Guilford Press, NY, hal. 177-178.
} 
Situasi dan kondisi kampanye secara terbuka kepada masyarakat membuat para caleg ingin menonjolkan diri demi elektabilitasnya di daerah konstituennya. Pada dasarnya pada caleg tahu kantongkantong suara mereka, para caleg sudah memetakan dan memprediksikan berapa kotak suara mereka di daerah pemilihannya, bahkan dia tahu seberapa populer mereka di tengah-tengah masyarakat.

Untuk memaksimalkan itu tentu caleg membutuhkan stategi politik untuk meraih perolehan suara yang unggul dibanding dengan pesaingnya. Di pemilu proporsional terbuka pada saat ini, para caleg sadar betul bahwa persaingan yang sehat merupakan fenomena yang tidak dapat dihindarkan dalam iklim demokrasi. Untuk dapat memegang kekuasaan, caleg partai politik atau seorang kandidat harus memenangkan pemilihan umum dengan perolehan suara terbanyak diantara kontestan-kontestan lainnya.

Para konstestan harus mampu memenangkan persaingan dalam koridor ketentuan pemilihan umum, semakin bertambahnya partai politik membuat persaingan semakin tinggi pula. Masyarakat juga dihadapkan pada lebih banyak alternatif pilihan selama periode pemilihan umum. Maka dari itu yang harus dijual oleh para kontestan pemilu adalah progam-porgram yang "menyentuh hati masyarakat". Dengan kata lain, programnya itu tidak perlu muluk-muluk, tetapi mudah dijelaskan dan mudah pula dipahami oleh pemilih. Tidak perlu mengumbar janji yang tidak rasional, karena khususnya di Kota Pekanbaru banyak pemilih yang rasional dibandingkan dengan yang tidak rasional.

\section{Dengan Memakai Sistem Apapun Ruang Money Politik Akan tetap Selalu Terbuka.}

Pemilu di Kota Pekanbaru kecedasan pemilih itu sudah baik, lantaran Kota Pekan baru dari segi pendidikan masyarakatnya sudah baik. Sebagian masyarakat Kota Pekanbaru meyakini bahwa cara-cara yang lebih elegan dan terhormat adalah pilihan yang tepat untuk para caleg, walaupun sebagian caleg juga tidak dapat menafikan bahwa perilaku politik uang adalah salah satu cara yang ampuh untuk memenangkan suara dalam pemilu. Cerminan perilaku politik uang ini secara sengaja dilakukan baik secara terang-terangan maupun cara yang sangat halus kepada konstituennya. Hanya saja, money politik ini sesuatu yang sulit untuk dibuktikan dikarenakan di dalam kontestasi pemilu segala seuatunya pasti membutuhkan ongkos politik. Antara ongkos politik dan money politik ibarat 2 sisi mata uang yang tidak dapat dipisahkan, namun dalam bahasa undang-undang tetap disebutkan ada kategori yang termasuk money politik. 
Ongkos politik selama kampanye merupakan bukan kategori pelanggaran dalam pemillu. Semua biaya-biaya ini merupakan konsekuensi untuk mengumpulkan masa kampanye. Bahkan ketika masa sosialisasi dilakukan tidak menutup kemungkinan justru masyarakat memanfaatkan untuk minta bantuan kepada pasangan calon. Apakah tindakan demikian dikategorikan sebagai tindakan "money politik".

Tegasnya ongkos politik adalah keseluruhan biaya yang harus dikeluarkan oleh kandidat dalam rangka mencapai tujuan kegiatan politik tertentu. Dalam pemilihan legislatif tahun 2014 di Kota Pekanbaru, peneliti menemukan adanya money politik yang dilakukan oleh beberapa orang dari calon legislatif dari beberapa partai politik. Gambaran rekapitulasi pelanggaran pemilu pemilihan legislatif di Kota Pekanbaru Tahun 2014:

\section{Tabel 1}

Rekapitulasi Pelanggaran Pemilu Pemilihan Legislatif Di Kota Pekanbaru Tahun 2014

\begin{tabular}{|l|l|c|c|}
\hline No. & \multicolumn{1}{|c|}{ Jenis Pelanggaran } & Jumlah Kasus & Persentase \\
\hline 1. & Dugaan Tindak Pidana Pemilu & 16 & $30 \%$ \\
\hline 2. & Dugaan Pelanggaran Administrasi & 16 & $30 \%$ \\
\hline 3. & Dugaan Pelanggaran Pemilu & 22 & $40 \%$ \\
\hline & Jumlah & 54 & $100 \%$ \\
\hline
\end{tabular}

Sumber: Data Olahan PANWASLU Kota Pekanbaru Tahun 2014

Dari tabel di atas dapat dilihat bahwa laporan pelanggaran tindak pidana pemilu (money politik) yang masuk ke Panwaslu Kota Pekanbaru sebanyak 16 kasus atau $30 \quad \%$ dari 54 kasus/pelanggaran. Politik uang yang dilakukan oleh calon legislatif Kota Pekanbaru hampir terjadi di semua kecamatan yang ada di Kota Pekanbaru. Politik uang yang mereka lakukan seperti pembagian uang, sembako, jilbab dan lain sebagainya dengan tujuan agar mereka dipilih oleh masyarakat. Sistem apapun yang dinginkan kalau minset berpikir yang menjalankan sistem ini itu salah, pasti ada celah untuk berlaku salah. Jadi sistem proporsional terbuka sudah baik kita gunakan, tinggal kita perbaiki dimana letak salahnya, bukan mengembalikan lagi ke sistem proporsional tertutup. Mengembalikan ke proporsional tertutup itu sama saja memperlemah penguatan demokrasi yang sedang kita bangun.

Sungguhpun begitu, tidak semua masyarakat pemilih serta merta mau menerima politik uang. Kendati bisa saling menguntungkan bagi kedua bilah pihak, tetap harus berusaha sedemikian rupa untuk menindak secara tegas terkait dengan pelanggaran pemilu. Oleh karenanya, tranparansi dalam pemilu mesti ditingkatkan. Peran Bawaslu saja tidak cukup untuk menghentikan politik uang, 
maka dari itu dibutuhkan kesadaran oleh semua komponen masayarakat akan bahaya politik uang.

3. Nomor Urut Bawah Tetap Punya Kesempatan Untuk Memenangkan Perolehan Suara.

Dengan sistem proporsional terbuka sekarang memberikan semacam peluang untuk promosikan dirinya kepada konstituennya, walaupun dengan nomor urut terbawah sekalipun. Meski begitu caleg berharap diletakkan pada nomor urut yang ke atas, jika memungkinkan nomor urut teratas. Ada pengaruh atau tidaknya, yang jelas sebagian masyarakat meyakini dengan nomor urut paling atas memberi peluang lebih besar dibandingkan di bawah karena mudah mengingatnya.

Caleg yang ada dalam partai politik lebih memacu untuk aktif di masyrakat, lebih "mengupgred" elektabilitas di dapilnya. Jadi dapat disimpulkan untuk keterpilihan untuk menjadi anggota legislatif tidak harus selalu soal punya kemampuan modal yang besar (uang), tetapi lebih kepada bagaimana caleg memaksimalkan potensi "jaringnnya" di masyarakat untuk selalu meningkatkan elektabilitas di dapilnya.

Secara umum sistem proporsional terbuka ini ada keberhasilan dari sistem politiknya. Di proporsional terbuka ini, kompetisi itui lebih sehat, walaupun ada gesekan, menandakan caleg itu bekerja, sehingga ada upaya untuk memenangkan dengan adanya gesekan tersebut. Adanya gesekan dalam persaingan dalam memenangkan suara itu lebih baik dari pada caleg yang "santai" dan kelihatan pasrah untuk bersaing memperebutkan suara.

4. Sistem Proporsional Terbuka Lebih Melegitimasi Kedaulatan Rakyat Ketimbang Sistem Proporsional Tertutup.

Hubungan proporsional terbuka dengan soal legitimasi pada pemilu 2019 adalah masyarakat memilih orang yang mereka anggap itu memiliki kemampuan, kemudian yang paling banyak inilah yang paling legitimate. Yang dipilih ini bukan nomor urut tapi orang yang bersangkutan, disini berlaku dapat legitmasi yang kuat seusai dengan tujuan pemilu. Spirit proporsional terbuka adalah kepercayaan rakyat kepada pemilu ini semakin tinggi.

Menjaga kepercayaan kepada pemilu juga tergantung dari sistemnya. Jika, sistem yang dibuat membuat suara rakyat tidak bernilai, dan hanya ditentukan oleh oligarki partai maka pada gilirannya membuat legitimasi keterpilihannya lemah dipandang masyarakat. Soal legitimasi ini akan bersinggungan dengan kedaulatan itu berada di tangan rakyat sepenuhnya dalam memilih 
wakilnya di parlemen, kedaulatan itu berada di tangan rakyat bukan pada partai politik

\section{Sistem Proporsional Terbuka Lebih Menigkatkan Partisipasi Masyarakat.}

Menurut politikus Saan Mustafa dari Partai Nasdem, dalam sebuah statemennya menyatakan mendukung sistem proporsional terbuka. Pertama, sistem ini dianggap memperkuat partisipasi publik karena membuka hak pemilih memilih anggota legislatif secara langsung dan terbuka. Yang kedua, ingin kita hindari tumbuhnya kembali elit partai di dalam menentukan calon prioritas/titipan/dianak "emaskan" dalam partainya. Sistem proporsional tertutup memupuskan semangat atau keinginan agar partai politik yang ada di Indonesia merupakan partai yang lahir dari tengah masyarakat, muncul dari daerah kemudian mencapai kancah nasional. Sebab dalam sistem proporsional tertutup keputusan datang dari pusat.

\section{B. Pandangan KPU Kota Pekanbaru Melihat Perbandingan Kedua Sistem Pemilihan Proporsional \& Tertutup.}

\section{1) Sistem Proporsional Terbuka Dari Segi Teknis Pelaksanaan Pencoblosan Surat Suara Agak Ribet dan Lama.}

Berkaca dari pemilu 2019 kemaren di Kota Pekanbaru proporsional terbuka bagi pemilih repot ketimbang tertutup, kalau tertutup itu cuma logo partai, kalau terbuka harus mencamtumkan list nama caleg. Konsekuensinya kalau secara teknis bisa dilihat dari tingkat suara yang tidak sah itu jauh lebih tinggi ketimbang 2019. Artinya suara tidak sah cukup tinggi baik di nasional maupun di Kota Pekanbaru itu sendiri. Sedangkan untuk suara sah presiden itu lebih rendah. Karena gambar presidennya cuma 2 dan ukuran gambarnya besar, sangat mudah untuk dicoblos. Dari soal sisi demokratis jelas lebih demokratis adalah proporsional terbuka. Sistem ini lebih berdaulat, karena dia tidak ditentukan oleh partai, tapi langsung rakyat yang memilih siapa yang dipercaya wakilnya nya di DPR.

KPU mengeluhkan sistem pemilu serentak pada 2019 kemaren yang terlalu ribet, dan memakan waktu yang sangat lama, sehingga berpengaruh kepada kerja KPPS, yang direkap bukan hasil suara partai saja, tapi masing-masing caleg harus diteliti satu-satu. Lihat tabulasi nama caleg masing-masing dan disesuaikan dengan nomor urut partainya. Harapan dan rekomendasi KPU untuk perbaikan pemilu adalah teknis lebih dipermudah bagi pemilih. Beban berat bagi penyelenggara kalau harus lembur sampai 24 jam. Terutama sekali bagi pemilih, model kamaren banyak yang merasa kebingungan karena banyaknya yang dicoblos, kemudian pemilih banyak yang tidak mengenali para caleg yang ada dalam gambar tersebut. 


\section{2) KPU Kota Pekanbaru Menilai Proporsional Terbuka Lebih Meningkatkan Partisipasi Pemilih Ketimbang Tertutup.}

Kelebihan proporsional terbuka di pemilhan serentak 2019 di Kota Pekanbaru menjadikan tingkat partisipasi itu jauh meningkat dibanding tahun sebelumnya. Dari data olahan KPU angkanya mencapai 78,15\% tingkat kehadiran pemilih di TPS, melebihi target KPU sebesar $75 \%$.

Tabel 2.

Persentase Perbandingan Tingkat Partisipasi Pemilih di Kota Pekanbaru tahun 20172019:

\begin{tabular}{|l|c|c|c|}
\hline \multicolumn{1}{|c|}{ Tahun } & $\mathbf{2 0 1 7}$ & $\mathbf{2 0 1 8}$ & $\mathbf{2 0 1 9}$ \\
\hline Total Partisipasi Pemilih & $51,9 \%$ & $62,73 \%$ & $78,15 \%$ \\
\hline Total Tidak Memilih & $48,1 \%$ & $37,27 \%$ & $21,85 \%$ \\
\hline
\end{tabular}

Sumber: Diolah dari KPU RI 2017-2019.

\section{Tabel 3.}

Perbandingan pemilih dan total pengguna hak pilih di Kota Pekanbaru tahun 2017-2019:

\begin{tabular}{|l|c|c|c|}
\hline \multicolumn{1}{|c|}{ Tahun } & 2017 & 2018 & 2019 \\
\hline Total Pemilih & 568.744 & 472.681 & 491.047 \\
\hline Total Pengguna Hak Pilih & 295.402 & 314.879 & 383.753 \\
\hline
\end{tabular}

Sumber: Diolah dari KPU RI 2017-2019.

Berdasarkan paparan dari tabel di atas maka dapat diketahui bahwa angka partisipasi masyarakar dalam menyalurkan hak piihnya di tahun 2017 ada $51,9 \%$. Tentunya ini masih jauh dari target nasional yang sudah terlanjur dipatok pada angka 75\%. Namun sedikit ada perbaikan di tahun 2018 mencapai angka $62 \%$, namun angka ini juga belum bisa melampaui target nasional yang dipatok KPU di atas 75\%.

Di tahun berikutnya, angkanya baru melampaui target dengan persentase pemilih mencapai 78,15\%. Tinggginya angka capaian pemlih ini bisa dijelaskan karena disatukan dengan paket pemilihan presiden. Antusias dan animo pemilih yang luar biasa pada pemilu serentak 2019 kamaren disebabkan karena "panasnya" pertarungan antara kedua figure capres yakni Prabowo Subianto dan Joko widodo sebagai petahana.

Sebagai penyelenggara KPU Kota Pekanbaru juga ikut merasakan dampak sistem pemilihan proporsional terbuka. Dengan banyaknya calon yang ikut serta dalam kontestasi, membuka persaingan secara terbuka untuk mengajak pemilih untuk mencoblos mendatangi TPS. Bagi KPU sebenarnya proporsional terbuka ini memberi keuntungan dari segi meningkatkan partisipasi pemilih datang ke TPS. Akan tetapi menurut KPU, baik sistem proporsional terbuka maupun tertutup, KPU siap menjalankan sesuai aturan yang diamanahkan dalam peraturan perundang-undangan.

\section{Pandangan Bawaslu Pekanbaru Tentang Kedua Sistem Pemilihan Umum.}




\section{1) Bawaslu Pekan Baru "Proporsional Terbuka Tergantung Dari Militansi Partai Dan Pengkaderan Politik".}

Menurut Ketua Bawaslu Pekanbaru persoalan money politik dalam pemilu itu tanggung jawab bersama, termasuk penyelenggara, dan yang paling bertanggung jawab adalah partai politik. Pemilu yang dilakukan pada 2004 dan 2009 berdasarkan nomor urut (proporsional daftar tertutup) tidak menghapus money politik. Sebenarnya persoalan money politik itu tergantung dari partai politiknya. Dari analisis temuan di lapangan bahwa sistem pemilu proporsional terbuka maupun tertutup tetap saja membuka peluang kepada caleg untuk tetap melakukan money politik.

Perbedaannya terletak pada proporsional tertutup, uangnya bisa saja terdistribusikan kepada elit partai (Pimpinan Pusat Partai) yang sangat menentukan berdasarkan pesanan caleg. Semakin banyak caleg menyumbang ke partai politik besar harapan untuk diletakkan pada nomor urut teratas dan jelas menentukan sekali keterpilihan caleg untuk mendapatkan kursi. Dengan demikian tidak perlu yang di bawah nomor urut bekerja terlalu ekstra, sebab suaranya juga akan tidak terlalu menentukan untuk bersaing dengan nomor urut terartas.

Gaya semacam ini sangat menjadikan partai oligarkis, paterlistik dan tidak demokratis dalam menentukan wakil rakyat yang terpilih. Menurut Bawaslu kalau proporsional tertutup partai politiknya yang bermain, yang dilaporkan adalah caleg-calegnya. Secara umum untuk Kota Pekanbaru yang perlu dihindari adalah praktik pemborosan dan tidak efesien selama kampanye, kemudian bagaimana penyelenggara mesti bekerja secara profesional dan penuh tanggung jawab, menjaga kenetralan (independensi lembaga) serta menggalakkan anti politik uang kepada semua peserta pemilu. Terutama parpol berkomitmen untuk selalu menjunjung tinggi integritas, sprotifitas dan akuntabilitas. Apabila ini sudah terlaksana dengan baik, maka ketegangan konflik akan jauh berkurang, dan pemilu akan berjalan secara aman, damai dan sukses melahiran pemimpin yang demokratis.

2) Sistem Proporsional Daftar Terbuka Memberikan Kesempatan dan Peluang Yang lebih Besar Kepada Caleg Perempuan.

Di dalam riset penelitian ini, Kota Pekanbaru mempunyai banyak pemilih yang rasional, kecerdasan pemilihnya bagus, dan pemilih di Kota ini punya perhatian khusus terhadap keterwakilan perempuan pada pemilu. Ada peningkatan angka yang lebih baik dalam keterwakilan perempuan baik di tingkat DPRD Kota Pekanbaru maupun DPRD Provinsi Riau.

Peningkatan ini tidak bisa dilepaskan dari perubahan sistem proporsional tertutup ke sistem proporsional terbuka. Sebagaimana yang diketahui dalam aturan undang-undang pemilu, partai wajib memenuhi kuota $30 \%$ keterwakilan perempuan dalam parlemen. Walaupun Kota Pekanbaru belum sampai memenuhi kuota 30\%, tapi keterwakilan perempuannya 
tertinggi dibanding kota dan kabupaten yang lain di Provinsi Riau. Untuk perwakilan DPRD Kota Pekanbaru, dari 45 kursi terdapat 12 kursi untuk perwakilan perempuan. Sedangkan di Provinsi Riau, keterwakilan perempuan di DPRD mengalami peningkatan. Pada periode 2004-2009, anggota DPRD perempuan berjumlah 6 (enam) orang dari 45 anggota, dan pada periode 2009-2014, jumlah mereka meningkat menjadi 7 (tujuh) orang dari 45 orang anggota. Meskipun angka tersebut meningkat, tetapi belum dapat memenuhi "tantangan" pemerintah dengan memberikan quota $30 \%$ untuk perempuan.

Sistem proporsional daftar terbuka sebagaimana yang diamanatkan oleh pasal 6 ayat 1 UU No. 12 tahun 2003 memungkinkan kaum perempuan untuk terpilih. Di sisi lain, pasal 67 ayat 1 Undang-Undang No. 12 tahun 2003 menyebutkan bahwa: "urutan nama calon anggota DPRD Provinsi, DPRD Kabupaten dan Kota untuk setiap daerah pemilihan disusun oleh KPU Provinsi, KPU Kabupaten dan Kota, berdasarkan nomor urut, jadi yang ditetapkan partai politik peserta pemilu sesuai dengan tingkatannya."

Dengan demikian, jelaslah bahwa muaranya terletak pada kebijakan partai politik. Dengan sikap politik masing-masing partai politik yang mengikuti pemilu legislatif tahun 2014-2019, dari sejumlah 45 orang calon anggota legislatif yang lolos seleksi, terdapat 8 orang perempuan, dan laki-laki 37 orang. Secara keseluruhan, quota $30 \%$ yang diamanatkan oleh undangundang No.12 tahun 2003 untuk 2014-2019 berdasarkan jenis kelamin dapat dilihat dalam rincian tabel sebagai berikut:

Tabel 4.

Anggota DPRD Riau Tahun 2014-2019 menurut jenis kelamin:

\begin{tabular}{|l|l|c|c|c|}
\hline No & Nama Partai & Laki-laki & Perempuan & Jumlah \\
\hline 1. & Golkar & 4 & 3 & 7 \\
\hline 2. & Demokrat & 4 & 2 & 6 \\
\hline 3. & PDIP & 5 & - & 5 \\
\hline 4. & Gerindra & 3 & 1 & 4 \\
\hline 5. & Hanura & 4 & - & 4 \\
\hline 6. & PAN & 4 & 1 & 5 \\
\hline 7. & Nasdem & 3 & - & 3 \\
\hline 8. & PKB & 4 & - & 4 \\
\hline 9. & PKS & 2 & 1 & 3 \\
\hline 10. & PPP & 4 & - & 4 \\
\hline Jumlah & 37 & 8 & 45 \\
\hline
\end{tabular}

Sumber: Marwah, Vol.XIII No.2 Desember Tahun 2014

Terlepas dari implementasi kuota 30\% keterwakilan perempuan, disadari atau tidak, banyak hambatan yang ditemui oleh perempuan untuk berkiprah di dunia politik, seperti budaya patriarkhi, kultur dan sistem politik yang tidak menguntungkan posisi perempuan, sampai kepada 
aspek internal perempuan itu sendiri. Padahal dengan sistem proporsional daftar terbuka membuka peluang yang lebih adil bagi perempuan untuk tampil eksis dalam percaturan politik praktis.

\section{Solusi Terhadap Permasalahan Proporsional Terbuka Di Kota Pekanbaru.}

Dikatakan ada perubahan semenjak refromasi ini tentu saja ada, namun reformasi yang dibangun untuk mewujudkan sistem kepemiluan dan kepartaian yang paripurna masih jauh panggang dari api. Maka dari itu strategi yang ditawarkan oleh peneliti adalah sebagai berikut:

1) Menghemat Biaya Kampanye Dan Korupsi Pemilu Dengan Pengawalan Dana Kampanye.

2) Reformasi Masalah Partai Politik Melalui Undang-Undang Parpol Secara Komprehensif.

3) Perluasan Basis Partai Pada Kelompok Marginal (Kelompok Disabiltas, Masyarakat Adat, Perempuan, Buruh, Petani, Nelayan.

4) Partai Baru Harus Dimulai Dari Bawah Supaya Ada Basis Konstituen.

5) Pentingnya Untuk Penguatan Partisipasi Warga .

6) Memperbaharui Seleksi Perekrutan Parpol dan Penguatan Kader Berbasis Pengetahuan

7) Metode Kampanye Yang Mengutamakan Prinsip Dialog Interaktif

\section{Kesimpulan dan Saran}

Tinjauan sistem proporsional terbuka dalam pemilu legislatif 2019 terhadap dinamika demokrasi di Kota Pekanbaru menunjukkan ada progres yang lebih disukai partai politik politik ketimbang proporsional tertutup. Pada prinsipnya dari hasil penelitian tidak ada satupun sistem pemilu yang netral. Pilihannya terhadap sistem apa yang hendak diadopsi bergantung dari apa sesunggunya tujuan akhir yang ingin dicapai para pengambil kebijakan. Namun dari partai politik di Pekanbaru sepakat bahwa sistem pemilu dengan representasi proporsional terbuka dianggap lebih adil dibandingkan dengan sistem proporsional tertutup karena pertimbangan kursi yang diperoleh partai politik.

Bahwa sistem yang dijalankan dengan sistem proprosional terbuka ini belum dijalankan secara konsisten dalam pemilu legislatif di Pekanbaru. Peneliti menyimpulkan sistem pemilu sesungguhnya berkorelasi erat dengan sistem kepartaian. Partai politik menghadapi persoalan yang sama yaitu rendahnya tingkat kepercayaan mayarakat, padahal di sisi lain karakterristik partai politik pada umumnya hampir sama yaitu ditandai dengan under institutionalization (tidak terinstitusionalisasi dengan baik), pengorganisasian yang minim sumber daya, tidak berpengalaman, dan lemahnya hubungan partai dengan konstituen.

Proporsional daftar terbuka itu lebih rentan terjadi di level masyarakatnya, kerentanan terhadap politik uang, tapi kalau sistem proporsional tertutup justru di partai politik dan peserta pemilu itu sendiri. Situasi ini tidak saja akan mendorong perpecahan internal partai, tapi juga merusak hubungan partai dengan konstituen. 
Di daerah pekan baru partai cenderung oligarkis, sentralistik, paternalistis dan partai belum diberikan otonomi untuk sesuatu kebijakan yang stretagis termasuk dalam penentuan pemilihan kepala daerah dan perekrutan caleg di tingkat internal partai politik.

Sistem pemulu proporsonal yang ada sekarang belum bisa menjawab persoalan kepemiluan, namun bukan berarti sistem proporsional tertutup lebih baik. Persoalannya karena sistem yang ada belum menyentuh pada akar persoalan kepemiluan kita yang sangat mahal dan syarat money politik. Hal yang mendasar dan harus segera perlu direfromasi adalah undang-undang kepartaian yang pada gilirannya mempengaruhi kepada undang-undang kepemiluan kita, diantara saran peneliti terhadap perubahan iru adalah:

1. Menghemat biaya kampanye dan korupsi pemilu dengan pengawalan dana kampanye

2. Reformasi masalah partai politik melalui UU partai politik secara komprehensif

3. Pentingnya Untuk Penguatan Partisipasi Warga

4. Mempengaruhi seleksi perekrutan parpol dan penguatan kader berbasis 


\section{Daftar Pustaka}

A.Z. Nasution, 1995, Konsumen dan Hukum, Sinar Harapan, Jakarta.

Diamond, Larry dan Leonardo Molino. 2005. "Asseesing The Qualitt of Democarcy". The John Hopkins University Press, Biltomore.

Habernas, Jurgen. 1996. "Between Factsand Norm". Polity Press, Cambride.

Revitch, Diare dan Abiggil Therstrom (ed). 2005. Demokrasi Klasik dan Modern ditejemahkan oleh Hermoyo. Jakarta: Yayasan Obor Indonesia, Jakarta.

Robert, Andrew. 2010. "The Quallity of Democracy in Eastern Europe: Publik Prefernces and Policy Reform. "University Press, Cambride.

Santoyo Purwo, 2014 "Merancang Arah Baru Demokrasi Indonesia Pasca Reformasi”, KPG (Kepustakaan Populer Gramedia), Jakarta.

Sugiono, 2012. MEletode Penelitian Kuantitatif, Kualitatif dan R \& D. Alfabeta, Bandung Shumpeter Joseph. 1950. Capitalism, Sosialism, and Democracy. Happer, Network.

Pito Andrianus Toni et all. 2006. Mengenal Teori-Teori Politik Dari Sistem Politik Samoai Korupsi. Nuansa, Bandung.

Yin, RK 2011. Qualititative Research: Form Star to Finish, N.Y: The Guiford Press, NY.

Ayu Pertiwi Diah, Sistem Pemilu Proporsional Daftar Di Indonesia: Melahirkan Korupsi Politik? Jurnal Trias Politica, Universitas Riau Kepulauan, Vol.2, No.1, PP.1-14.2018.

Doni Ramdani Muhammad dan Fahmi Arisandi. Pengaruh Penggunaan Sistem Pemilihan Umum Dewan Perwakilan Rakyat Proporsional Daftar Terbuka. Jurnal Reehtsvinding. Univeristas 17 Agustus 1945. Vol,3.PP.1-11, 2014.

Silalahi Agus, "Korelasi Pengaturan Sistem Pemilu Proporsional Terbuka Barbasis Suara Terbanyak Dengan Korupsi Politik di Indonesia". Jurnal Yustisia, Univeristas 11 Maret. Vol 4.No.1.PP.1-14, 2015.

https://www.republika.co.id/berita/nasional/politik/14/03/19/n2o11c-hasil-riset-inijumlah- diakses tanggal 17 agustus 2019.

Arba, (2015). Indonesian Agrarian Law, Sinar Grafika, Jakarta.

Chomzah, Ali A., (2002). Land Law, Land Law Series I Awarding State Land Rights, Land Law II Certificate Series and Its Problems, Literature Achievement Publisher, Jakarta.

Gautama, S., (1990). Interpretation of the Basic Agrarian Law, Citra Aditya Bakti, Bandung.

Hatta, M. (1977). Elaboration of Article 33 in the Constitution of 1945, Mutiara, Jakarta.

Harsono, B., (2000),. Indonesian Agrarian Law, Djambat, Jakarta.

Indonesia, Constitution of 1945. 
Indonesia, Law Number 5 of 1960 concerning Basic Regulations on Agrarian Principles.

Indonesia, Law Number 4 of 2009 concerning Mineral and Coal Mining.

Indonesia, Government Regulation 24 of 1997 concerning Land Registration.

Indonesia, Law Number 4 of 1996 concerning Mortgage Rights.

Indonesia, Constitutional Court Decision No. 001-021-022 / PUU-I / 2003 concerning Judicial Review Number 20 of 2002 on Electricity.

Manan, B., (1995). Growth and Development of the Constitution of a Country, Mandar Maju, Bandung.

Muljadi, K. and Widjaja, G., (2008), Rights to Land $i$ the Series of Assets, Kencana, Jakarta.

Santoso, U., (2010), Registration and Transfers of Land, Kencana, Jakarta.

Santoso, U., (2015), Land Acquisition of Land, Kencana, Jakarta.

Sitorus, O. and Dyawati, N., (1994), Land Rights and Condos A Legal Review, Dasamedia Utama, Jakarta.

Zarqoni, Muhammad M., (2015), Land Rights, Acquisitions, Origins and Derivatives, and Their Relationship with Legal Guarantees and Property Rights Protection, Achievement of Publisher Library, Jakarta. 